\title{
WHAT DETERMINES THE INNOVATIVENESS OF POLISH FAMILY FIRMS? EMPIRICAL RESULTS AND THEORETICAL PUZZLES
}

This article will review and synthesize the existing research on the innovativeness of Polish family firms in order to separate universal factors that influence the degree of innovativeness of firms from the factors which distinctively influence the innovativeness of family firms. To better assess the innovation propensity of family firms the author will work out the typology by combining the variety of innovations with particular features of family firms and the industrial context. A more nuanced approach will help to understand why the academic literature is inconclusive with regards to the question of whether family firms are anti-innovative (as some authors claim), pro-innovative or ambivalent with regard to innovations. In particular it will be argued that when assessing family firms' innovativeness special attention needs to be paid to the impact of the management of intergenerational change on the propensity to innovate, as this process relates to the capacity for investments into innovativeness and the time horizon of the owner's decisions.

Keywords: small business, family firms, innovativeness, innovation mechanisms; intergenerational change, innovation capacity, path diversity

Family firms dominate all national economies, accounting for between 60 and 80 percent of their gross national product and slightly less for employment (La Porta et al., 1999, p. 471-517.).

According to a report of PWC (2014) between 60 and $85 \%$ of all European firms are family firms, which constitute $60 \%$ of employment and generate 60 million jobs in the private sector. The overwhelming majority of family firms is composed of small and medium sized companies, which are responsible for $85 \%$ of the new jobs. Family firms are increasingly seen as a secure part of a sustainable economy, since they are particularly resistant to crises - they are more rarely closed and they fire less frequently their employees, thereby reducing the negative social consequences of economic crises (Safin, 2007). The view of family firms radically alters when economic processes are analyzed from the point of view of the factors of economic development. From this perspective, the most important are the processes of effective innovation, since they lead to the creation of new fields of economic expansion involving the positive side of the process of creative destruction. This aspect is inseparable from technological changes and other economic chocks. In such conditions family firms are considered a hindrance to economic developments as they are deemed insufficiently innovative. But, is such a statement legitimate in light of economic and managerial theories? Is it backed by existing empirical evidence?

In this article we analyze the characteristics of family firms from the point of view of factors encouraging or discouraging innovativeness. We then confront theoretically derived generalizations through the use of existing empirical data concerning the innovativeness of family firms. Finally, we develop a conceptual model, which shows the possible areas of impact of intergenerational succession on the degree of innovativeness and the type of innovations that are likely to be developed or adopted by family firms.

A plethora of concepts of family firms: an attempt at their simplification

Many authors stress the fact that there is no universal agreement on a definition of family firms and that in the literature there are various concepts hidden behind the same term. This lack of a single definition has been recently indicated in the report for the European Parliament as an obstacle to the creation of a public policy towards family firms: ,...this lack of reliable and com- 
parable data can hinder policy decision-making and may mean that the needs of family businesses are not being met" (Niebler, 2015, p. 5.).

However, what policy makers bemoan as an obstacle to designing efficient public policy, might not be a drawback in academic debates, which need to recognize the nature of a research problem. Furthermore, this issue forces us to reject the search for a representative family firm in each national economy, since family firms strongly differ in ways the families are involved in the daily activities of family firms and family firms differ in the same industry, firm size, firm-level skills and wages, capital intensity and in firm-level productivity.

Despite this, several decades of family firm research has allowed us to simplify the picture of a highly heterogonous world of family firms and to single out the most important criteria which then allows us to distinguish family firms from non-family firms. The first criterion is the ownership of a firm (full ownership or dominant ownership), the second points to the influence of family on the management of firms, thirdly, sometimes considered the least important, involves taking into account the self-identification of owners and managers of a firm and the aspiration of incumbent owners to pass the ownership and influence over firm's management to the next generation (so called "dynastic aspirations").

Even if one applies just one criterion, such as ownership, it is possible to see the differences in the degree of ownership concentration (from 100\% downwards) and its dispersion across various members of family, whose borders are defined by the strength of family ties and other cultural factors. The influence of such factors is easily seen, when we compare family firms across cultural areas (from Europe to China) or over time $\left(19^{\text {th }}\right.$ Century European family firm with a family firm in Europe of changing family models). Furthermore a family can be an owner not of a singular firm, but of
If we add to the criterion of ownership the criterion of management, we need to consider the complexity of management structures and practices (family firm governance). This dimension is highly influenced by a firm's size. The larger a firm is, the more complex its organizational structures are and the limits to the managerial control by one or several family members are correspondingly firmer. Family firm governance may require an organizational form that solves the problem of delegating powers and monitoring the behavior of other (family and non-family) middle and higher level managers.

In general, newly founded firms are fragile and their „,death rate” is high. The first critical threshold in the life cycle of a firm appears within first year, when the number of new firms falls by two thirds. The extinction of firms is a natural phenomenon and more surprising is the fact that approximately $14 \%$ of firms are transferred to the second generation. Dynastic aspirations of the founders and owners of new firms are faced with a decreasing survival rate, although their subjective aspirations are not necessarily emboldened by excessive optimism ${ }^{1}$. First generation family firms need however to nourish "dynastic aspirations" since they support the preparations of family members for just such an eventuality, assuming the sustainability of the firm. Assuming that three quarters of all firms are first family firms, three quarters of them will be also "last generation" family firms lacking the capacity to found a family business dynasty, but still with a strong presence of family in the ownership and management of a firm.

In the countries, which have recreated a private market economy, after the fall of the planned economy, most firms are first and last generation family firms. If on average $14 \%$ of newly created firms pass to the second generation, one can expect the formation of 210 thousand second generation family firms in Poland ${ }^{2}$,

Number of enterprises in selected EU countries in 2011 (in thousands)

\begin{tabular}{|l|l|l|l|l|l|l|l|l|}
\hline Country & Italy & UK & $\begin{array}{l}\text { Germa- } \\
\text { ny }\end{array}$ & France & $\begin{array}{l}\text { C z e c h } \\
\text { Republic }\end{array}$ & $\begin{array}{l}\text { Hunga - } \\
\text { ry }\end{array}$ & Poland & $\begin{array}{l}\text { R o m a - } \\
\text { nia }\end{array}$ \\
\hline Number & 3825 & 1704 & 2190 & 2567 & 1007 & 529 & 1520 & 426 \\
\hline
\end{tabular}

Source: Eurostat - Your Key to European Statistics http://ec.europa.eu/eurostat/

a group of firms (family business group) or control a whole chain of firms via the principle of a pyramid control, or create and discontinue firms (enter and exit) by managing a kind of family venture fund which operates with differentiated assets and differentiated investment temporal horizons.
140 thousand in the Czech Republic, 70 thousand in Hungary and 57 thousand in Romania. (Table 1)

The combination of these three factors and other contextual variables generates strong heterogeneity of family firms resulting from the variety of ways in which a family interacts with the firm. This variety, on 
the one hand, creates a continuum with self-employed and microenterprises in which family is an implicit, informal and contextual factor, and, on the other, firms which have grown so rapidly that within one generation they have become family controlled public companies quoted on stock exchanges, or they have become the source of personal or family wealth without dynastic aspirations ${ }^{3}$.

\section{Risk and orientation to socio-emotional wealth}

Family firms are en masse considered less innovative than non-family firms, and this feature seems to originate from their propensity to avoid risks. The reasoning goes as follows: innovation requires risk taking, family firms are rise averse, hence family firms are less innovative. However, this thesis is more assumed than proven as empirical verification is methodologically challenging, if not outright impossible, due to the conceptual and factual complexity of innovations. In the literature we find similar statements to one based on an empirical study of a sample of Columbian firms. Its authors: González, Guzmán, Pombo and Trujillo write: „Risk aversion pushes firms toward lower debt levels, but the need to finance growth and the risk of losing control cause family firms to employ higher debt levels" (González et al., 2012, p. 2319.). Such ambivalent statements point to existing tensions between orientation towards growth and the fear of losing control over the firm and this tension influences the choice of the method for financing growth. If however growth is necessary, but impossible without innovation, family firms might overcome their aversion to risk. Risk propensity is strictly linked with the orientation towards growth, and the latter depends on the industry and life cycle of the firm. It is observed that family firms are chiefly present in mature industries since they are risk averse. However, this tendency might be due to the fact that we identify firms as family firms after prolonged periods of business activity and this means that interdependency is an endogenous factor. In new industries, like information technology, the newness of such industries and their turbulent conditions, make the presence of family firms (and especially $2^{\text {nd }}$ generation family firms) less frequent and less visible.

Small family firms are also deemed as less innovative than small non-family firms since they are considered as plagued with inertia - in small firms the habits and routines shaped by owner/founder strongly frame the functioning of the company and the behavior of its employees. As a result family firms might misread market signals, be slow to react to market changes, badly adapt to changing circumstances or miss market opportunities. This means that the strong figure of a success- ful founder and owner might with time reduce innovative orientation of the family firm that he had founded.

Family firms are also often called seen as having a long term orientation embedded in strong family values and a commitment to keeping the firm in the hands of the family for future generations. In family firm "constitutions" - documents for owning families, it is often written that "this family business will last forever" (Harris et al., 1994, p. 159-174.).

Like all firms that care about innovativeness, family firms need to create a culture of innovation that is environmentally supportive of "creative change that produces meaningful results" (Schmieder, 2014, p. 18.). The culture of innovation is necessary "both to exploit existing resources (e.g., focus on efficiency enhancement) and explore new opportunities" (Schmieder, 2014, p. 21.).

In the contemporary environment of open markets the sustainability of family firms requires constant development based on innovation, as well as the selection of well skilled and committed employees who are able to adopt technological changes. The leaders of family firms are aware of the importance of such factors and they are aware that sustainable family firms need to create an environment suitable for knowledge creation, development and transfer, as can be seen in Table 2.

Table 2 .

Key internal challenges for the family firms in the next five years

\begin{tabular}{|l|l|l|}
\hline Types of challenges & 2012 & 2014 \\
\hline Need to continuously innovate & $62 \%$ & $84 \%$ \\
\hline Attracting the right skills talent & $58 \%$ & $61 \%$ \\
\hline Retaining key Staff & $46 \%$ & $48 \%$ \\
\hline Reducing costs & n/a & $44 \%$ \\
\hline Need for new technology & $37 \%$ & $41 \%$ \\
\hline Need to professionalise business & n/a & $40 \%$ \\
\hline Company succession planning & $32 \%$ & $36 \%$ \\
\hline Conflict between family members & $9 \%$ & $11 \%$ \\
\hline
\end{tabular}

Source: Makó et al. (2015): Recommendation to Policy Makers (Draft version). Intergenerational Succession in SMEs Transition, INSIST. Budapest: Budapest Business School - Faculty of Finance and Accounting, p. 4.

In large firms the processes of knowledge creation and knowledge sharing have a more formalized nature than in smaller firms. It seems that the size of the company is a decisive factor. A large family firm does not differ from a large non-family firm, since the number of employees, the pace of their rotation and the complexity of internal processes and interactions push for formalization (the creation of procedures).

In small firms the creation, development and the transfer of knowledge takes on an informal character 
(Wach, 2014). This means that knowledge is strongly linked to the experiences generated by work and problem solving, and that such knowledge is rarely written in formal documents. This may generate the risk of a loss of acquired knowledge and the lack of the possibility to transfer it, if the persons that have accumulated knowledge and store it, go away or are fired by the firm.

If a small family firm is a first generation family firm, its main figure is the founder/owner. He is the central node for all of the most important business and social processes of the firm. His knowledge predominantly derives from his own experience or from sources with which he has had direct contact. The diffusion of knowledge in the firm depends on the quality of relations between him and key employees of the firm.

If analyzed from the perspective of socio-economic wealth, family firms are seen as endowed with high human capital (a high quality of social ties) and strong symbolic capital (Popczyk, 2014). This is a source of their strength, but it might also be a source of some problems. The symbolic capital is linked with the family identity of the firm, which might be linked with a given type of industry. For example the name of Rothschild is associated with finances, and not with food production, Barilla, on the other hand, is strongly associated with Italian pasta. If a family firm is strongly linked with a given industry, it is often assumed that the continuation of such an activity is always desired. But, if such continuity leads to losses, or eventually, to bankruptcy, then such a continuation is not a good solution. In this case the family of owners should build business alternatives and withdraw from loss-making activities before the possibility of bankruptcy emerges.

We can say that family firms face the problem of "symbolic stickiness". Usually they have to build their own symbolic capital and reputation around the family name and certain types of activities. For example, if a Polish firm like Blikle is associated with an image of a multigenerational family firm active in doughnut production, such a family firm is somehow symbolically constrained to continue this kind of business activity even if this may limit the firm's growth potential.

Facing uncertainty about the future and being oriented to the long run, the family of the owners might be induced into making personal sacrifices by self-commitment to a traditional activity, especially if there are public expectations that the family business should remain concentrated on a given enterprise.

It is worth noting that the tendency towards long term commitment to a given field of business activity is in a natural way strengthened by the specificity of family firm's assets (including specific managerial and technical skills and an intimate knowledge of a given sector of the economy). Both symbolic factors and the assets' specificity may cause the "innovative" decision to shift to a different type of business or to exit from a loss-making business activity to not be taken at all or to be taken only after a significant delay. It is certainly true that family firms "actively mix the resources of firms and the resources of family" in order to assure their business success (Haynes et al., 1999, p. 225-239.).

The interdependence of the development of firm and the changes in the owning family creates symbolic and real overlaps, which might in turn create obstacles to the identification of emerging business opportunities. If a family firm functions for several generations in a given branch, the likelihood of shifting to a different business activity is small and requires bold decisions. We can thus speak about 'identity induced blindness' to new business opportunities.

These factors have been noticed by family business researchers who observed that a strong emotional commitment to the activity which had been founded by ancestors, and a strongly felt moral duty and responsibility for employees and for local community all constrain family firm owners from following a certain path in the business. Lansberg (1999) observed that family members often avoid or delay the necessity to innovatively change the business track, not because they do not follow financial indicators, but because they are emotionally attached to the existing type of activity. Abandoning and exiting from a historically shaped activity might be seen as something that weakens the family status and its reputation in a community. The combination of such factors might lead to the situation in which family members suppress the idea of moving away from a given business activity.

The tendency of family firms to get locked into obsolete (loss-making activities) is well illustrated by Italian company Falck, which was founded in 1906 by Giorgio Enrico Falcka in Sesto San Giovani near Milan as a steel working company. After successful development in the first 5 decades, the company started to make losses in its core activity in the 1970s and after almost 20 years departed from steelmaking in the first half of 1990s. From then on the Falck Group has focused on renewable sources of energy, investments in real estate and financial intermediation. In his memoires one of the leaders of the $4^{\text {th }}$ generation, Alberto Falck, wrote "in the past our firm passed through 3 succession processes, and each succession was a challenge to family values. In our case the commitment to steelmaking was winning over other factors. That is why we have stuck to the steel industry for so long" (James, 2006, p. 161-171.). The history of the successful transformation of Falck shows that the members of the owning family were aware of the fact that in an age of rapid technological change "an early exit might become something 
necessary in order to regain most of the invested assets and to redirect them into activities that generate a higher rate of return" (Harrigan, 1980, p. 599-604.). Contemporarily the sustainable development of family firms requires recognition of the importance of threats and opportunities created by technological change and the growing internationalization of markets. Maintaining economic activities in sectors of low growth or not adjusting to technological change have diminished the likelihood of passing the company to the next generation, thus it undermines the aspirations for dynastic succession.

\section{Types of innovation and heterogeneity of family firms}

Innovativeness relates to the capacity of a firm to make discoveries and to create new solutions through experimentation and creative problem solving (Lumpkin Dess, 1996). Such a general statement creates no obvious need for a more precise definition. In the academic literature there are many definitions of innovation which stress various aspects of the concept. Still, it seems reasonable to reduce the complexity of innovation to three criteria, which highlight the essence of innovations:

1. innovation is a novelty (something new, a new product, service or process) understood in absolute or relative (contextual) meaning,

2. the scale of innovation might be different: from relatively minor innovation to large scale (disruptive) innovation,

3. innovation is created not for the sake of itself, but it needs to be accepted by consumers.

If we take into consideration only these three criteria, we realize how many varied types of innovation there are in firms: from absolute innovation, which has a large scale impact and create new branches of the economy to local innovations, tiny in scale and exploiting market niches.

Sometimes it is expected that family firms need to create disruptive innovations, despite the fact that such innovations are extremely rare, and when they appear, they might not come from one source, or from a single firm. The Internet is one such disruptive innovation. Its origins go back to academic research and attempts to create tools for the transmission and exchange of data. It is a result of public spending and the work of many anonymous researchers, but public opinion ascribes the greatest innovativeness to companies, which, as in the case of Google, have designed algorithms for the data search and the most accurate information matching. In economic development one large scale innovation that was finance from public sources opened the way to many smaller, but more effectively commercialized, innovations.

For economic development a crucial problem exists in the passage from an invention to a (patented) innovation. The growth of basic knowledge is the main source of inventions. Inventions, such as new drugs are patented by their creators (or firms) in a form of patent race and they might have great importance to patients (customers) as they might prolong their lives (or greatly increase utility). For firms the patented innovations might be a source of increased profits, but innovations as such might depend on earlier scientific discoveries. One should note that innovative firms might designs health products (dietary supplements) which do not rely on any significant scientific discoveries, they are not innovative in an absolute way, but still they serve to offer valuable market products. For example, the market of dietary supplements in Poland was valued at $850 \mathrm{~m}$ euro in 2015 (Puls Biznesu, 2015) and the domestic supply is provided by approximately 300 small and medium sized enterprises which almost without exception can be counted as family firms. From a more general perspective it seems that there is a positive correlation between the type of industry and the density of innovative firms. In industries such as semiconductors and electronic components, chemicals or computer hardware a large share of firms can be classified as innovative. In traditional industries such as bakery there are much less opportunities for innovative companies.

The analysis of forms and degrees of innovations get complex if we take into account the four types of innovations: product innovation, process innovation, marketing innovation and organizational innovation. Two types of innovations, namely process and organizational innovations, are internal to a firm - they cannot be captured from outside without targeted research. The public attention is directed to product and marketing innovations, which are visible from outside and sometimes spectacularly attractive.

The innovativeness is fostered by external factors (Kellermanns et al., 2012). Innovations of firms depend on several institutional factors like the quality of tertiary education, basic research and technological infrastructure, economic openness, R\&D expenses, active labour market policies for retraining and supporting job searches and the availability of equity financing. That is why the Global Innovation Index shows generally a high positive correlation between the degree of innovativeness and the GDP per capita, which in turn is strongly correlated with the quality of the institutional environment.

International comparisons of innovativeness measure input and output of innovativeness, namely the 
number of patent applications, the number of researchers and the expenditures on R\&D. Inputs and outputs are linked by processes, which take place within enterprises and in an external environment. For example, the number of granted patents depend on the design of patent law. The US has the highest number of patent applications: in this country the number of patent applications increased from 164.5 thousand in 1990 to 578.8 thousand in $2014^{4}$, but when interpreting such numbers one should take into account the peculiarity of national patenting systems. In the case of the US the patenting system allows for cheap and relatively cheap patenting of even small inventions. Furthermore a strong system of property rights allows for the existence of secondary markets of patents where patents are resold and find their ways to commercialization. Thus, it is legitimate to speak about national systems, which influence the innovativeness of companies and are decisive for the level of private returns on innovations and more broadly on research and development.

In some countries the process of defending innovation and the registration costs create obstacles for small firms. The administrative costs of patenting distort patenting and their commercial utilisation in favor of larger firms. That is why researchers such as Galasso and Schankerman (2015) have confirmed the importance of patenting offices and administrative courts for the patenting activities of small firms. They have discovered that the court's decisions on which patents to invalidate decrease the future likelihood of firm's patenting by $50 \%$, and they have documented that the significance of patent protection depends on the size of the firm, the importance of patented technologies for competitive strategies and on the competitive environment. If a small firm gets its patent invalidated in the court trials and the patent relates to its core technology, then its innovativeness efforts get harmed. Such an occurrence does not affect large firms, which continue pro-innovativeness activities and attempts to register patents even if they lose one of their key patents. Generally speaking higher protection granted by patents does increase the market power of an innovator (Hopenhay - Mitchell, 2001, p. 152.), but patenting regulations, as noted by Galasso and Schankerman (2015), do influence the innovativeness of small firms in following ways:

- they can strengthen the market position of small firms by permitting them to sell licenses to large firms that can develop them and commercialize,

- they can facilitate the access to financing and venture capital,

- they can improve the bargaining position of small firms in their attempts to use the inputs composed of licensed products or solutions.
It is generally recognized that conducting $R \& D$ activities and developing innovative products, services and processes requires appropriate resources and especially appropriate human capital and financing resources. If however firms do not aspire to developing proper innovations, still they need similar resources to absorb (buy and implement or identify and imitate) existing innovations. From this perspective small firms are at a disadvantage in comparison to large firms and this factor seems more important than the familiness of the firm.

\section{The innovativeness of Polish family firms: empirical results}

The discussion so far has served to show the complexity of innovativeness analysis and the ambiguity of empirical research results. It has been shown that innovations are contextual and their meaning needs to be understood in the local market and institutional environment. That is why all international comparisons suffer from the flaw that they reduce the complexity of innovativeness to some simple indicators of inputs, process or outcomes. Still they might provide some useful, although preliminary information. Thus, the widely known Global Innovation Index developed by Cornell University and INSEAD indicates that the Polish economy is not very innovative. In the 2015 Ranking Poland is placed in $46^{\text {th }}$ position behind Hungary $\left(35^{\text {th }}\right)$, France $\left(21^{\text {st }}\right), \mathrm{UK}\left(2^{\text {nd }}\right)$, and with Switzerland ranked as number one $^{5}$. The empirical results regarding Poland need to be interpreted against such general conditions.

The existing empirical research about the innovativeness of family firms is scarce and relies on the analysis of small samples and cases. Quantitative, representative research with large samples, on the other hand, do not differentiate between family and non-family firms, while focusing dominantly in Poland on the category of small and medium sized enterprises. Thus, the research conducted in 2015 with a sample of 7,000 micro- and small enterprises showed that the majority of them did not implement any innovation, and only 5\% prepared innovations whose cost exceeded 25,000 euro (Wedziuk, 2016). When asked about the type of implemented innovations, $26 \%$ of inquired companies answered that they introduced product innovation, whereas $17 \%$ said they implemented process innovations. The conclusions of this and other similar research empirically confirm the theoretical prediction that the overwhelming majority of micro- and small firms does not innovate and does not grow. Still the companies that grow do innovate, but researchers select them because they have grown since they rather illustrate and not test the link between innovation and growth. Based on an educated guess one can state that among the firms that innovate 
and grow almost all are family firms. For instance Fakro - a company owned by the Ryszard Florek family has become the second largest European producer of roof windows and has for years been researched and shown as an innovative company which introduces technological changes improving the quality of products. It uses new technologies like 3D printers to develop new products and runs its own research laboratory to develop and test new products. But, sampling from the group of visibly successful and innovative family firms introduces a strong bias in an estimation of the likelihood of similar cases.

More generally the empirical research of innovativeness of family firms suffers from the longevity bias. Family firms become family firms through internal perception and external recognition only after a substantial time: a firm existing for one to five years can hardly be called a family firm. Still in most innovative sectors (like pharmaceuticals or informatics) innovations are generated by young, small firms that develop patented products or, after dynamic growth, are purchased by larger firms that develop and commercialize their products. Similarly start-up entrepreneurs increasingly depend on large firms as suppliers or customers, for venture finance, exit opportunites, knowledge (production, markets and R\&D) and for opening new markets. In academic research and in public perception family firms are older firms in more mature (less disruptive) industries. Hence, the perception of family firms is as conservative, choosing and functioning in traditional industries and sectors. To disentangle the link between the size, age and innovativeness of firms is an investigative challenge yet to be resolved.

An interesting, but under-researched problem relating to family firms regards the impact of succession on a firm's innovativeness. Based on existing research we can estimate that on average $14 \%$ of family firms are transferred to the second generation and $3 \%$ to the third generation. It seems thus that succession is not a phenomenon with heavy economic importance, but if one considers, as it is in the case of Poland, that there are approximately 1.5 million functioning firms, of which $85 \%$ are family firms and $14 \%$ are transferred to the second generation, the efficient succession relates thus to approximately 180 thousand firms. Furthermore, family firms that have completed succession, are undergoing succession or plan succession are relatively larger, better managed family firms. This adds to the economic importance of the problem. The academic and policy weight of the problem is evident: badly managed (or not prepared) succession might undermine innovativeness and sustainability of family firms. But, in Poland there are no empirical results allowing for an estimation of the scale of the problem.

\section{Conclusions}

The academic literature is inconclusive with regards to the question of whether family firms are anti-innovative (as some authors claim), pro-innovative or ambivalent with regard to innovations (König et al., 2013). If researchers avoid easy conclusions, then it seems family firms themselves struggle with the myth of family firms' inherent anti-innovativeness. Innovation research seems to focus on a sample of highly visible large scale innovations in the sectors in which family firms are not visible. However, a growing academic base of literature identifies other types of innovations and forms of innovativeness in which family firms excel (Więcek-Janka - Pawłowska, 2014).

The precise diagnosis pushes us not towards a too broad question of whether family firms are innovative or not, but towards a question of which family firms are innovative, in which dimensions and to what degree. This leads to methodological problems with designing research allowing to identify pro- and anti-innovativeness mechanisms which might characterize family firms (Marjański - Sułkowski, 2014).

In the case of Poland it seems confirmed that a generally low level of innovativeness reduces the need to innovate. Furthermore, small family owned companies do not have the resources necessary to develop innovative activities or to meet the challenge of innovative external competitors. Moreover, the innovativeness of firms is not stimulated by the institutional environment, including the quality of the legal system and weak links between firms and universities.

Polish family business research converges with international academic literature concluding that family firms are not inherently anti-innovative. In order to last over generations they need to be innovative. Future research, due to the high heterogeneity of family firms, could advance our understanding of innovativeness mechanisms by contextualizing general knowledge through including family, firm and industry specific factors. The attention of the public policy makers should focus on the improvements of the general institutional environment, since the attempts to identify and support transformational entrepreneurial family firms - those that introduce major innovations and make substantial contributions to growth - are methodologically and operationally untenable.

\section{Notes}

${ }^{1}$ Not only entrepreneurs overestimate the likelihood of an effective „dynastic" succession. Similar tendencies characterize other professions as well. Thus, for example, $94 \%$ of professors from American universities believes they are better than an average professor (Price, 2006).

${ }^{2}$ In countries like Poland the actual share of firms that will be transferred to the second generation will be likely lower due to the small size of private 
firms: an average number of employees in a firm amounts in Poland to 5.5 persons, whereas in all EU countries it amounts to 6.1 persons.

${ }^{3}$ Microsoft or Google are here obvious examples.

${ }^{4}$ See: U.S. Patent Activity Calendar Years 1790 to the Present, available: http://www.uspto.gov/web/offices/ac/ido/oeip/taf/h_counts.htm)

${ }^{5}$ See: Global Innovation Index - https:/www.globalinnovationindex.org/ content/page/data-analysis/ - access 26 May 2016.

\section{References}

Galasso, A. - Schankerman, M. (2015): Patents and Cumulative Innovation: Causal Evidence from the Courts. Quarterly Journal of Economics, 130, p. 317369.

González, M. - Guzmán, A. - Pombo, C. - Trujillo, M. A. (2012): Family Firms and Debt: Risk Aversion versus Risk of Losing Control. Journal of Business Research, 66/11, p. 2308- 2320.

Harrigan, K. R. (1980): Strategy formulation in declining industries. Academy of Management Review, 5, p. 599-604.

Harris, D. - Martinez, J. I. - Ward, J. L. (1994): Is strategy different for the family-owned business? Family Business Review, 7, p. 159-174.

Haynes, G. W. - Walker, R. - Rowe, B. R. - Hong, G. $S$. (1999): The intermingling of business and family finances in family-owned businesses. Family Business Review, 12 (3), p. 225-239.

Hopenhayn, H. - Mitchell, M. (2001): Innovation variety and patent breadth. Rand Journal of Economics, 32 (1)

James, H. (2006): Family Capitalism. Wendels, Haniels, Falcks and the Continental European Model. Cambridge: Belknap Press

Kellermanns, F. - Eddleston, K. - Sarathy, R. - Murphy, F. (2012): Innovativeness in Family Firms: A Family Influence Perspective. Small Business Economics, 38(1), p. 85-101.

König, A. - Kammerlander, N. - Enders, A. (2013): The Family Innovator's Dilemma: How Family Influence Affects the Adoption of Discontinuous Technologies by Incumbent Firms. Academy of Management Review, 38, p. 418-441.

Lansberg, I. (1999): Succeeding generations: Realizing the dream of families in business. Boston: Harvard Business School Press

La Porta, R. - López de Silanes, F. - Shleifer, A. (1999): Corporate ownership around the world. Journal of Finance, 54(2), p. 471-517.

Makó, Cs. - Csizmadia, P. - Heidrich, B. (2015): Recommendations to Policy Makers (Draft version). Intergenerational Succession in SMEs Transition, INSIST. Budapest: Budapest Business School - Faculty of Finance and Accounting
Marjański, A. - Sułkowski, Ł. (2014): Methodology of Family Business Research (Metodyka badań firm rodzinnych). Przedsiębiorczość i zarządzanie, tom $\mathrm{XV}, 7 / \mathrm{II}$, p. 11-21.

Lumpkin, G. T. - Dess, G. G. (1996): Clarifying the Entrepreneurial Orientation Construct and Linking it to Performance. Academy of Management Review, 21, p. 135-172.

Niebler, A. (2015): REPORT on Family Business in Europe. European Parliament (Plenary sitting). Committee on Industry, Research and Energy, RR/10677364EN.doc - A8-0223/2015

Popczyk, W. (2014) : Social Capital in Family Firms. Structure and mechanism for the creation of family capital (Kapitał społeczny w firmach rodzinnych. Struktura i mechanizm kreowania kapitału rodziny). Przedsiębiorczość i zarządzanie, tom XV, 7/ II, p. 133-145.

Price, C. P. (2006): Are You as Good a Teacher as You Think. Thought \& Action, Fall

Puls Biznesu (2015): PMR: Good Forecasts for the Market of Dietary Supplements (PMR: Dobre prognozy dla rynku suplementów diety), 26 maja.

PWC (2014) : Family Business Survey. http://www.pwc. com/gx/en/services/family-business/family-business-survey.html.

Safin, K. (2007): Family Enterprise - its nature and strategic behaviour (Przedsiębiorstwa rodzinne istota i zachowania strategiczne). Wydawnictwo Akademii Ekonomicznej im. Oskara Langego we Wrocławiu, Wrocław

Schmieder, J. (2014): Innovation in Family Business. Succeeding through Generations. London: Palgrave Macmillan

Wach, K. (2014): Role of knowledge in the internationalisation process: an empirical investigation among Polish businesses. in: Kiendl-Wendner D. - Wach K. (eds.) (2014): International competitiveness in Visegrad countries: macro and micro perspectives. Graz: Fachhochschule Joanneum (ISBN: 978-3200-03673-4)

Wedziuk, S. (2016): Najmniejsi skąpią na innowacje (trans.: Small Business Saves on Innovations). Puls Biznesu, 5 February

Więcek-Janka, E. - Pawłowska, M. (2014): The Question of Technological Innovation in Family Enterprises (Problematyka innowacji technologicznych w przedsiębiorstwach rodzinnych). Przedsiębiorczość i zarządzanie, tom XV, 7/ II, p. 149-160.

Article arrived: June 2016. Accepted: Sept. 2016. 